Междисциплинарное сотрудничество...

УДК 34.037

DOI https://doi.org/10.17308/vsu.proc.law.2020.4/3184

\title{
КОНФЛИКТ И СПОР: ВЗГЛЯД ЮРИСТА НА ИХ СУЩНОСТЬ, СООТНОШЕНИЕ И СПОСОБЫ РАЗРЕШЕНИЯ
}

\author{
О. А. Поротикова \\ Воронежский государственный университет \\ Поступила в редакцию 10 ноября 2020 г.
}

\begin{abstract}
Аннотация: анализируются соотношение категорий "конфбликт" и "спор" с точки зрения юриспруденции. Обсуждается взаилосвязь сущности конобликтов, их причин, видов и эбббективности защить нарушенных прав. Предпринилается попытка объяснить, почему право как наиболее фбормальный регулятор общественных отношений заленяет в большинстве случаев конфбликт на спор. Показывается тендениия развития совреленного права в направлении использования инструлентов и методик других социальных и гуманитарных наук - психологии, политологии, фбилологии и иных.

Ключевые слова: конфбликт, спор, урегулирование конфблктов, судебное разрешение споров, примирительнье прочедуры.
\end{abstract}

\begin{abstract}
: the article analyzes the relationship between the categories "conflict" and "dispute" from the point of view of jurisprudence. The relationship between the essence of conflicts, their causes, types and effectiveness of protection of violated rights is discussed. An attempt is made to explain why law, as the most formal regulator of social relations, replaces conflict with a dispute in most cases. The tendency of development of modern law in the direction of using the tools and methods of other social and humanitarian sciences - psychology, political science, philology and others is shown.
\end{abstract}

Key words: conflict, dispute, conflict resolution, court dispute resolution, conciliation procedures.

В юриспруденции долгое время не принято было употреблять термин «конфрликт». Дореволюционные юристы пользовались различными заменителями - «распри», «коллизии», но чаще всего - «споры». С них началась и потом просуществовала весь двадцатый век практика употребления именно слова «спор» для отображения любых противоречивых и правонарушающих ситуаций, требующих правового реагирования.

Советский период, несмотря на то что прошел в своем развитии целый ряд этапов - от полного отрицания дореволюционной терминологии до ее постепенного возрождения и восприятия, - никогда не отказывался от категории «спор» как наиболее формальной и максимально подходящей для права.

И только в конце 90-х гг. ХХ в. юристы понемногу стали осваивать конфликтологию, подпитываться из других наук, главным образом психологии и политологии, и, наконец, пытаться внедрить в право такое явление и обозначение, как «конфликт». Изначально этим занялись теоре-

(C) Поротикова О. А., 2020 


\section{Вестник ВГУ. Серия: Право}

тики права и конституционалисты ${ }^{1}$, именно им принадлежат первые и самые масштабные работы в области уже юридической конфликтологии ${ }^{2}$. При этом «спор» вовсе не уступил «конфоликту» свое место, а лишь позволил встать рядом.

Почему же термин «спор» так мил сердцу юристов? Все дело, видимо, в том, что конфликт это многослойное, сложное по своим причинам, структуре связей и протеканию явление, которое довольно сложно диагностировать и, тем более, урегулировать полностью. Для этого требуются не только специальные профессиональные методы, но и арсенал весьма специальных средств. Слово «конфликт» происходит от латинского conflictus, что в переводе означает «столкновение», но это мало что само по себе может объяснить, поскольку сталкиваться могут мнения, интересы, интерпретации фактов и т. п., далеко не все из этого будет конфликтом с точки зрения психологии, конфликтологии ${ }^{3}$ и, тем более, юриспруденции.

Результатом многочисленных исследований в области юридической конфликтологии на рубеже XX-XXI вв. стали попытки сформулировать универсальное понятие правового конфликта.

Одной из наиболее распространенных дефиниций была следующая: «Под юридическими конфликтами необходимо понимать прямое или косвенное противостояние (противоречие) субъектов права, обусловленное противоречиями их юридически значимых интересов, возникающее в связи с созданием, реализацией, применением, изменением, нарушением, толкованием права и разрешаемое в процессе правоприменения в особой процедурной форме в конкретных правоотношениях» ${ }^{4}$.

Ее развитие встречается в публикациях самых разных специалистов, например нотариусов: «Конфликт - это столкновение разнонаправленных целей, интересов, позиций или взглядов субъектов взаимодействия. $\checkmark$ 을 $Z$ ент, клиент - клиент, нотариус - нотариус. В основе любого конфлик¿े та лежит ситуация, включающая в себя некое противоречие, связанное 尺े либо с позициями сторон, либо взглядами и убеждениями, либо целями и средствами их достижения» ${ }^{5}$.

$354{ }^{1}$ См.: Чулюкин И. Л. Социальные конфликты и применение права : автореф. дис. ... канд. юрид. наук. Казань, 2001 ; Астахов П. А. Юридические конфликты и современные формы их разрешения : теоретико-правовое исследование : автореф. дис. ... д-ра юрид. наук. М., 2006 ; Москаленко М. Н. Сущность и специфика конституционных конфликтов на современном этапе развития Российского государства // Современный юрист. 2015. № 3. С. 54-70.

${ }^{2}$ См.: Юридическая конфликтология / отв. ред. В. Н. Кудрявцев. М., 1995 ; Юридический конфликт / О. А. Акопян [и др.] ; отв. ред. Ю. А. Тихомиров. М., 2018.

${ }^{3}$ См., например: Шайхутдинов Р. Г. Конфликтологическая программа построения гуманитарных дисциплин // Кентавр. М., 1993. № 2. С. 37-41.

${ }^{4}$ Третьяк И. А. Конституционно-правовой конфликт как вид юридического конфрликта // Конституционное и муниципальное право. 2020. № 5. С. 3-7.

${ }^{5}$ Кряжева С. Г. Конфликт в нотариальной практике : причины и стратегии разрешения // Нотариус. 2020. № 2. С. 15-17. 


\section{Междисциплинарное сотрудничество...}

Вместе с тем в подобном виде конфликт как понятие для права совершенно не применим, поскольку право не может ни повлиять, ни исправить взгляды, убеждения, цели и интересы. Почему приведенные определения, по мнению их авторов, касаются именно правовых конфликтов и что в них отличает правовые от всех иных видов конфликтов, остается неясным.

Справедливости ради нужно отметить, что в психологии, социологии и политологии, наиболее тесно исследующих сущность конфликтов, их структуру и динамику, также не получилось создать единое представление об этом многоаспектном явлении ${ }^{6}$, однако удалось серьезно продвинуться в этом направлении. Но прямое перенесение психологического понимания конфликта с добавлением слов «правовой» или «законные интересы» в юридическую действительность, что можно наблюдать в ранее приведенных определениях, не принесет никакой пользы правоприменению.

Право представляет собой наиболее формальный регулятор отношений по сравнению с иными соџиальными регуляторами (моралью, религией и т. п.), оно оперирует довольно ограниченным набором инструментов (правонаделением, обязыванием, ответственностью с использованием государственного принуждения). Поэтому юридическими средствами далеко не все можно уладить и поправить, а только то, что поддается формализации и внешнему проявлению, а впоследствии доказыванию в суде. Именно по этой причине, а вовсе не от недостатка желания, право не регулирует внутреннюю сферу человека - его мысли, чувства, эмоции, привязанности. Просто у юристов нет и не может быть средств, которыми все, что у человека в душе и в голове, можно было бы объективировать вовне, установить, подтвердить имеющимися средствами доказывания.

Право в объективном смысле ставит перед собой сложнейшую задачу - установить единые для всех участников общественных отношений правила поведения, обеспечив единые реакции за их нарушение. Поэтому главной ценностью правовых норм и их обязательным свойством является универсальность правил, не персонализированность, что достигают через идею формального равенства. В связи с этим все индивидуалистичное, персональное и детальное сбрасывается со счетов, не учитывается. Думается, это не недостаток права, а его необходимое качество, без которого право перестало бы быть собой и превратилось бы в свою противоположность - произвол.

Все сказанное позволяет увидеть, что тяготеющий к индивидуальности кондрликт (а он всегда максимально конкретный, связанный с определенными интересами и факторами, с персональными особенностями субъектов) трудно сочетается с целями и возможностями права.

${ }^{6}$ См.: Светлов В. А. Введение в единую теорию анализа и разрешения конфрликтов. М., 2013 ; Новосельцев В. И., Тарасов Б. В. Системная теория конфрликта. М., 2011 ; Аниупов А. Я., Шипилов А. И. Конфрликтология : учебник. М., 2015 ; Лефбевр В. А., Слолян Г. Л. Алгебра конфликта. М., 2009. 


\section{Вестник ВГУ. Серия: Право}

А как же спор? Ведь с точки зрения семантического значения этого слова он один из синонимов конфликта, почему с ним удобнее работать юристам? Думается, что на правовом языке спор не равен конфликту, а является его внешним воплощением, видимым для права формальным выводом из конфликта.

Так, если представить себе айсберг в качестве образа конфликта, то спор - это вершина айсберга, то что над водой, то что доступно фиксации и объективированию. Возьмем для наглядности в качестве модели конфрликт супругов, проживших вместе двадцать лет, а теперь решивших расстаться. Он складывается из массы отдельных недопониманий, интерпретаций, недоговоренностей, лжи, агрессии и прочего. Все это зарождалось, трамбовалось и достигло критического уровня. Может ли в этом затяжном конфликте помочь право? Самым формальным образом - увидев наверху спор, т. е. определенные требования, которые супруги адресуют друг другу, основанные на предложенных в нормах моделях. Любые супруги могут обратиться с требованием о расторжении брака или с требованием о разделе общего имущества. Этот сухой остаток - обмен требованиями, которые являются универсальными, - и есть то, что юристы называют спором. Очевидно, что вынеся решение о расторжении брака и разделив на основе норм права имущество, суд разрешит спор, но не излечит конфликт, а скорее обострит его.

Кому из юристов не приходилось слышать, как в ответ на желание сторон рассказать суду всю историю их взаимоотношений, все переживания по этому поводу, суд предупредит о необходимости заявлять только о том, что относится к делу или прямо объявит, что все это «лирика», не имеющая значения для разрешения спора по существу. И будет прав. Все это важно для урегулирования конфбликта, психолог обязательно это будет слушать и анализировать, но юристу (в особенности суду) для разрешения правового спора, т. е. оценивания обоснованности и законности заявленных требований сторон, это избыточная информация.

Спор для юриспруденции основан на нарушении прав и законных интересов одного лица другим, даже если это нарушение кажущееся. Где-то за спиной большинства правовых споров существует конфликт (межличностный, трудовой, корпоративный, структурный), но в силу спецификки и ограниченности юридического целеполагания и инструментария праву надо взять из конфликта какую-то видимую часть и переложить на язык прав, обязанностей и их нарушений.

Об этом наиболее аргументированно размышляют цивилисты, занимающиеся корпоративным правом, поскольку у них наглядно просматривается разница между корпоративными конфоликтами, которые очень разнообразны по своим причинам, имеют разный субъектный состав, этапы протекания и экономический эфрфект, и тем, что в АПК РФ для защиты корпоративных прав легально предусмотрен термин «корпоративный спор».

«Конфрликт представляет собой любое противоречие между сторонами корпоративных отношений (в том числе между акционерами/участника- 


\section{Междисциплинарное сотрудничество...}

ми, потенциальными акционерами/участниками, внутри хозяйственного общества). По нашему мнению, «корпоративный конфликт» является родовым понятием по отношению к специальному - «корпоративный спор». Разрешение конфликта возможно путем проведения переговоров, образования согласительной комиссии, а также в судебном порядке... Не случайно говорят, что любой неразрешимый конфоликт переходит в спор, который является прерогативой суда» ${ }^{7}$.

Пожалуй, единственное, где термин "конфликт» сразу получил свое признание и применение в праве - это обозначение им одной из проблем государственной службы - конфликта интересов ${ }^{8}$. Полагаем, связано это с тем обстоятельством, что конфликт интересов был сразу же легализован, т. е. довольно конкретно был описан в законе субъектный состав и суть данного явления. Термин стал специальным для юристов, опять же довольно формальным, поскольку действительно противоречие интересов никем не устанавливается, часто может фрактически отсутствовать, но это никак не скажется на квалификации ситуации в качестве конфликта интереса госслужащего. В таком же формальном виде он впоследствии был заимствован и частным правом в качестве особого института корпоративного права - сделок с заинтересованностью, в качестве одного из запретов для представительства в гражданском праве ${ }^{9}$. Из сказанного следует, что даже употребляемый в правовых текстах термин "конфоликт», получает в праве свое довольно выхолощенное содержание.

В последние десятилетия российское право обновляется применительно к своим задачам и оснащается неприменяемыми ранее средствами защиты участников отношений. Все больше в текстах законов появляются оценочные категории, воспринятые из нравственности и этики, такие как добросовестность, справедливость, разумность, требующие от судей и иных правоприменителей оценивания именно данной конкретной ситуации, отказываясь от высот формализма и приближаясь к отдельному случаю. Это требует расширения дискреционных полномочий суда, ухода от единого лекала для определенных категорий дел к инди-

${ }^{7}$ Лаптев В. А. Понятие корпоративных конфликтов. Разграничение понятий «корпоративный конфликт» и «корпоративный спор», «корпоративное поглощение» и "корпоративный захват» // Арбитражный и гражданский процесс. 2010. № 9. C. 28-32.

${ }^{8}$ См.: Казанцева Н. Г., Николаева С. Н. К вопросу о реализации законодательства по урегулированию ситуаций конфликта интересов // Государственная власть и местное самоуправление. 2020. № 4. С. 44-47; Венецкий М. М. Конфликт интересов // Законность. 2020. № 8. С. 24-27; Сурланидзе И. Н., Ерлолин А. В. Правовые и психологические аспекты конфликта интересов на государственной и муниципальной службе // Государственная власть и местное самоуправление. 2019. № 1. С. 37-42.

${ }_{9}^{9}$ См., например: Малкина В. И. Влияние конфликта интересов на институты гражданского права // Юрист. 2020. № 7. С. 31-37 ; Скловский К. И. Явный конфликт интересов органа управления и общества и его юридические следствия // Закон. 2019. № 3. С. 158-163. 


\section{Вестник ВГУ. Серия: Право}

видуальному разбору дела и защите прав конкретного лица в конкретной уникальной жизненной ситуации.

Указанные тенденции совпали или были синхронизированы с новыми трендами в развитии процессуальных форм защиты нарушенных прав и интересов. Сначала в цивилистическом процессе, а впоследствии и в публичном (уголовном, административном) стали внедряться разного рода примирительные процедуры как судебные, так и внесудебные. Иными словами, задачами права и процесса на современном этапе становятся не только формальная реакция на заявленные требования с общими мерками, но и попытка дать сторонам шанс найти обоюдное удовлетворение интересов в конкретной ситуации, сохранить в дальнейшем их отношения, создать условия сотрудничества в других областях их взаимодействия.

И вот уже в юридической науке и практике все больше заимствуются, привлекаются методы других областей знаний - психологии, фрилологии, социологии, конфликтологии, а термин «конфрликт» перестает быть совершенно инородным по отношению к праву. Ярким примером такого взаимодействия является процедура медиации, в которой независимый посредник создает условия для того, чтобы конфликтующие стороны услышали друг друга, прояснили свои интересы, поэтому ни медиатор, ни стороны не связаны рамками первоначальных требований, могут обсуждать одновременно иные проблемные вопросы, приходя к системному урегулированию кризиса в отношениях спорящих, по возможности, устраняя причины конфликта. При этом право поддерживает такие методы своими средствами - закрепляет механизмы обеспечения исполнения заключенных соглашений, упрощает возможности защиты их прав в судебном разбирательстве.

В то же время не стоит питать иллюзий относительно того, что юриспруденция когда-нибудь станет стремиться именно исчерпать различные конфликтные ситуации, это ей не свойственно. Происходящие изменения, связанные с обогащением права методами других наук, крайне полезны, они помогают делать правовые средства более эффективными, но они не должны и не смогут изменить природу права как социального регулятора.

Есть и еще один аспект, на который нельзя не указать в рамках обсуждения терминов «спор» и «конфликт» и их значения для юриста, связанный с современными тенденциями развития юриспруденции.

Право само по себе - конфликтоген, во многих его институтах и механизмах заложены причины противоречий для участников отношений. То, как формируются правовые правила и потом реализуются в судах, во многом способствует появлению и раздуванию конфликтов. Например, попытка универсализировать правовые правила сама по себе приводит к тому, что в ситуации исключений субъекты будут рассматривать норму как несправедливую, и это породит новые конфликты.

А столь важный для защиты нарушенных прав процессуальный принцип состязательности сторон сам по себе предполагает обострение 


\section{Междисциплинарное сотрудничество...}

конфликта, поскольку сторонам приходится занимать антагонистические, как им кажется, непримиримые позиции (истец - ответчик, обвинение - защита). Причем если в гражданском или арбитражном процессе состязательность лишь оформляет уже имеющиеся противоречия сторон в материальных правоотношениях и представляет собой лишь способ визуализации их спора, обеспечивая возможность «проговорить» свои претензии, то в уголовном процессе это именно дополнительное обострение.

На данную тему в уголовно-процессуальной науке написано немало работ ${ }^{10}$. Например, по мнению Т. В. Исаковой, «...можно смело утверждать, что законодательно закрепленный принцип состязательности является одним из структурообразующих факторов возникновения конфоликтов в уголовном процессе» ${ }^{11}$. Специалисты в области процессуального права подчеркивают, что из-за состязательности нередко приходится сталкиваться с конфликтами межличностного уровня у самих представителей сторон, а также защитников и обвинителей, поскольку им и суду необходимо давать оценку процессуальным действиям и решениям, которые с формальной стороны могут выглядеть законными и обоснованными, но по сути являться недобросовестными.

Профрессиональные юристы также выполняют полярные фрункции: адвокат - прокурор ${ }^{12}$; юрист в организации - контролирующий орган, что способствует развитию далеко не примирительных идей, а скорее принципа борьбы до победного конца, а иной раз и любыми средствами.

В таком контексте судам легче и честнее использовать формальноюридический подход, чем, пользуясь своим усмотрением, «затачивать» решение под конкретную жизненную ситуацию, поэтому нельзя сказать, что цель «исчерпания конфликта» может заменить в юриспруденции «разрешение спора». Вместе с тем можно только приветствовать те начинания, сопряженные с привлечением идей и методов иных социальных и гуманитарных наук, которые будут помогать и юристам, и гражданам әфффективнее защищать права и интересы.

${ }^{10}$ См.: Баев О. Я. Конфликты в деятельности следователя. Воронеж, 1981 ; Его же. Конфоликные ситуации на предварительном следствии (основы предупреждения и разрешения). Воронеж, 1984.

${ }^{11}$ Исакова Т. В. Состязательность российского уголовного процесса как структурообразующее начало конфоликтной деятельности участников уголовного судопроизводства // Администратор суда. 2018. № 1. С. 23-26.

${ }^{12}$ См., например: Гармаев Ю. П. Незаконная деятельность адвокатов в уголовном судопроизводстве : учебник. М., 2005. С. 66.

Воронежский государственный университет

Поротикова О. А., кандидат юридических наук, доцент кафбедры гражданского права и процесса

E-mail: olga.porotikova@mail.ru
Voronezh State University

Porotikova O. A., Candidate of Legal Sciences, Associate Professor of the Civil Law and Process Department E-mail: olga.porotikova@mail.ru 